\title{
Yield and Economics Performance of Green Gram as Influenced by Nutrient Management under Organic Farming
}

\author{
Kavita Bhadu $^{1 *}$, K.K. Agrawal ${ }^{1}$ and Rakesh Choudhary ${ }^{2}$ \\ ${ }^{1}$ Department of Agronomy, College of Agriculture, JNKVV, Jabalpur-482004, India \\ ${ }^{2}$ Krishi Vigyan Kendra, Ambala-133004, Haryana, India \\ *Corresponding author
}

\section{Keywords \\ FYM, Organic nutrient management, PSB, Rhizobium, \\ Vermicompost \\ Article Info \\ Accepted: \\ 28 February 2018 \\ Available Online: \\ 10 March 2018}

\section{A B S T R A C T}

A field experiment was conducted at research farm, Department of Agronomy, JNKVV, Jabalpur (M.P.) during, kharif season of 2016. A set of five organic nutrient management $\left[\mathrm{NM}_{1}(100 \%\right.$ nitrogen through $\mathrm{FYM}), \mathrm{NM}_{2}$ (100\% nitrogen through vermicompost), $\mathrm{NM}_{3}$ (50\% nitrogen through FYM + 50\% nitrogen through vermicompost + PSB @3 ml/l), $\mathrm{NM}_{4}(25 \%$ nitrogen through FYM $+25 \%$ nitrogen through vermicompost + Rhizobium +PSB @ $5 \mathrm{ml} / \mathrm{l}$ ) and $\mathrm{NM}_{5}$ (control)] were tested in Randomized Block Design with four replications. An organic nutrient management practices showed significant $(\mathrm{p}=0.05)$ effect on plant height, primary branches, total dry matter of green gram crop. The results revealed that yield attributing characters and yields were significantly influenced by the application of different organic nutrient management. Among the organic nutrient management, $\mathrm{NM}_{4}$ produced significantly higher pods per plant (25.93) and seeds per pod (11.47) as well as seed yield $(785.54 \mathrm{~kg} / \mathrm{ha})$ in green gram. The minimum values of yield attributes and yield were observed under $\mathrm{NM}_{5}$ (control). The Gross monetary returns (GMR), Net monetary returns (NMR) and B: $\mathrm{C}$ in green gram were maximum under $\mathrm{NM}_{4}$ (Rs 39332/ha, Rs 15392/ha and 1.64 respectively) and the values for GMR, NMR and B: C were minimum (Rs 35443/ha, Rs 16863/ha and 1.91, respectively) under $\mathrm{NM}_{5}$.

\section{Introduction}

Green gram (Vigna radiata $\mathrm{L}$. Wilezek) is one of the most important pulse crops grown in India. Green gram is short duration, drought tolerant pulse crop which also commonly known as "Mungbean". Its seed contains $24.7 \%$ protein as well as sufficient quantity of calcium, phosphorus and important vitamins. Due to its supply of cheaper protein source, it is designated as "poor man's meat" (Potter and Hotchkiss, 1997). Green gram is considered as a substitute of animal protein and forms a balanced diet when used with cereals.

Although, chemical fertilizer are playing a crucial role to meet the nutrients need of the crop. The imbalance and continuous use of chemical fertilizers has adverse effect on soil physical, chemical and biological properties thus affecting the sustainability of crop production, besides causing environmental pollution. The increased dependence on agrochemicals including fertilizers has led to 
several ill effects on the environment. In the process of finding an alternative to chemical agriculture, the organic farming is gaining a gradual momentum. Organic farming seems to be more appropriate because it considers the important aspects like sustainability of natural resources and environment. Organic agriculture is healthier not only to human and animals but also to environment, because they are produced without the use of synthetic inputs such as chemical fertilizers, pesticides and hormones etc. Among the means available to achieve sustainability in agricultural production, organic manures and biofertilizers play an important and key role because they exert beneficial effect on the soil physical, chemical and biological properties of soil for sustenance of soil quality and future agricultural productivity (Ramesh et al., 2008).

The farmyard manure (FYM) itself contains reasonable amounts of nutrients which become available to plants upon decomposition besides enhancing availability of native as well as applied nutrients (Chand and Subhash (2007).Vermicompost contains micro site rich in available carbon and nitrogen (Sudhakar et al., 2002). Worm cast incorporated soils are also rich in water soluble P (Gratt, 1970) and contained two to three times more available nutrients than surrounding soils (Sudhakar et al., 2002), which encourages better plant growth yield.

The phosphate solubilizing microorganisms (Pseudomonas) play an important role in conversion of unavailable inorganic $\mathrm{P}(\mathrm{Ca}-\mathrm{P}$, $\mathrm{Fe}-\mathrm{P}$ and $\mathrm{Al}-\mathrm{P}$ ) into available inorganic $\mathrm{P}$ forms through secretion of organic acids and enzymes (Singh M V 1999). Keeping the points in view the present experiment was under taken with the object to find out the Productivity and profitability of green gram as influenced by nutrient management under organic farming.

\section{Materials and Methods}

\section{Experimental site, soil and Climate characteristics}

Field experiment was conducted to study yield and economic performance of green gram as influenced by nutrient management under organic farming during kharif, 2016 Research Farm, Department of Agronomy, Jawaharlal Nehru KrishiVishwaVidyalaya, Jabalpur (M.P.) during kharif season 2016.Jabalpur comes under the agro-climatic zone classified as "Kymore Plateau and Satpura Hills" as per norms of National Agriculture Research project (ICAR) New Delhi.

The soil of the experimental field was sandy clay loam, neutral in reaction with medium OC contents, normal in EC and analyzing low in available $\mathrm{N}$, medium in available $\mathrm{P}$ and medium in available $\mathrm{K}$ contents. The initial soil characteristics of the experimental field are presented in table 1. Experimental site represented the arid climate average annual rainfall of about $\mathrm{mm}$. More than 80 per cent of rainfall is received in kharif season (JulySeptember) by the south west monsoon. During growing season, total rainfall received during the crop season was $1135.5 \mathrm{~mm}$, which was distributed in 45 rainy days. Maximum and minimum mean temperature ranged between $27.0^{\circ} \mathrm{C}$ to $33.0^{\circ} \mathrm{C}$ and $15.4^{\circ} \mathrm{C}$ to $24.5^{\circ} \mathrm{C}$ respectively. The relative humidity ranged between 82 to $94 \%$ in morning and 29 to $91 \%$ in evening. The sunshine hours varied between 0.0 to 9.3 hours/day (Fig. 1).

\section{Treatments and experimental design}

The experiment was laid out in randomized block design with four replications. Each replication consists of five treatments of organic nutrient management viz., $\mathrm{NM}_{1}(100$ $\%$ nitrogen through FYM), $\mathrm{NM}_{2}$ (100\% nitrogen through vermicompost), $\mathrm{NM}_{3}(50 \%$ 
nitrogen through FYM $+50 \%$ nitrogen through vermicompost + PSB @ 3 ml/l), NM (25\% nitrogen through FYM $+25 \%$ nitrogen through vermicompost + rhizobium +PSB @ $5 \mathrm{ml} / \mathrm{l}$ ) and $\mathrm{NM}_{5}$ (control). Treatments were randomized separately in each replication. Each plot measured $9.0 \mathrm{~m} \times 4.5 \mathrm{~m}$ with distance between row to row was $0.45 \mathrm{~m}$. Different combination of organic nutrients was applied as per treatment requirement with control (no use of fertilizer).FYM and vermicompost were applied basal after final field preparation.

\section{Crop establishment and management}

Seeds of black gram (Var. PDM-139 or Samrat) crop were inoculated with Rhizobium culture (as per treatment requirement). Crop was sown in rows $45 \mathrm{~cm}$ apart manually by using kudali. Seed were sown @ 15 kg/ha. Crop was sown on July $16^{\text {th }}, 2016$ and harvested on October $25^{\text {th }}$ 2016. Foliar spray of PSB was applied per treatment requirement at 20, 25 and 30 DAS. The plots were supplied with different proportions of FYM and Vermicompost as per treatment were applied only to fulfill the need of major nutrient $(\mathrm{N})$ in the crop as per recommendation on per hectare area basis. FYM and Vermicompost were applied basal after final field preparation. Seed inoculation (Rhizobium culture) required quantity of the cultures, i.e. @ $200 \mathrm{~g}$ culture per $10 \mathrm{~kg}$ seed was mixed to $10 \%$ sugar solution to form slurry. The slurry was sprinkled on seeds and mixed with hand to make a uniform coating over the seeds and then the seeds were spread on a polythene sheet in shade to avoid direct sunlight. Seeds were sown immediately (Tilak, 1991). The infestation of seasonal weeds was controlled twice with the help of khurpi at 20 and 40 days growth stages. Three spray of cow urine @ $80 \mathrm{ml}$ per litre of water was given in forenoon, first at $25 \mathrm{DAS}$ and rest was repeated on weekly interval for control of sucking pest. Three spray of Neem oil @ $10 \mathrm{ml}$ per litre of water was given in afternoon, first at 25 DAS and rest was repeated on weekly interval as insect repellent. The physiological maturity of all the treatments was judged visually before the crop was harvested.

\section{Sampling technique, observations and analysis}

Five plants were selected randomly from each plot for sampling purposes and observations were recorded. Dry matter production/plant (g) with the help of three plants were uprooted at 30, 45 and 60 DAS respectively from each plot and allowed to dry in an oven at $65^{\circ} \mathrm{C}$ till to reach at constant weight and finally mean was computed. In order to eliminate the border effects, one outer row and $50 \mathrm{~cm}$ from both the ends were removed first from each plot keeping net plot $8.0 \mathrm{~m} \mathrm{X} 3.6 \mathrm{~m}$. Before harvesting the net plots, five randomly marked plants were removed for post-harvest studies. The threshing was done plot wise by labour with the help of sticks.

The weight of cleaned grains from each net plot was recorded in $\mathrm{kg}$ per plot and then converted into $\mathrm{kg}$ per hectare. The observations on yield attributes (pods per plant and seeds per pod) and yields were recorded. The harvest index is the ratio of economic (seed) yield out of total biological (seed + straw) yield which is expressed in percentage. It estimates the partitioning of the dry matter between seed and straw. Finally, economic viability of the treatments was also determined in terms of cost of cultivation, gross monetary returns, net monetary returns and B: $\mathrm{C}$ ratio on/hectare basis. Data pertaining to various parameters were tabulated and subjected to statistical analysis for interpretation of results.

\section{Results and Discussion}

An organic nutrient management practices showed significant $(\mathrm{p}=0.05)$ effect on plant 
height, primary branches, total dry matter of green gram crop study.

Effect of different organic
management treatments on
attributes

Plant height of green gram was significantly influenced by various organic nutrient management treatments at harvest (Table 2). Among all the organic nutrient management, under application of $25 \%$ nitrogen through FYM, 25\% nitrogen through vermicompost inoculation with Rhizobium and PSB $\left(\mathrm{NM}_{4}\right)$ plant height was significantly $8.3 \%$ higher at harvest and minimum in under control $\left(\mathrm{NM}_{5}\right)$ treatment, respectively. These results are in collaborated with those of Selvakumar et al., (2012), Bahadur and Tiwari (2014) and Hussain et al., (2014).

The number of primary branches/plant was significantly higher $(26.7 \%)$ with $25 \%$ nitrogen through FYM, 25\% nitrogen through vermicompost, inoculation with Rhizobium and PSB@5ml/1 (NM4) at harvest followed by $21.5 \%$ higher with application of $50 \%$ nitrogen through FYM, 50\% nitrogen through vermicompost and inoculation with PSB@3ml/1 (NM3) over control (NM5) (Table 2). The integrated use of organic manures with biofertilizer under the NM4 treatment would have facilitated better growth and development ultimately results more number of branches per plant. These results are in with close agreement those of Murugan et al., (2011) and Bahadur and Tiwari (2014).

All the organic nutrient management treatments significantly affected the total dry biomass recorded at 30, 45 and 60 DAS. The $25 \%$ nitrogen through FYM, 25\% nitrogen through vermicompost, Rhizobium inoculation and PSB spray @ 5ml/l $\left(\mathrm{NM}_{4}\right)$ recorded significantly more dry weight plant $^{-1}$ followed by application of $50 \%$ nitrogen through FYM,
50\% nitrogen through vermicompost and PSB spray@3ml/1 $\left(\mathrm{NM}_{3}\right)$, the significantly lowest dry weight of nodules plant ${ }^{-1}$ with $\mathrm{NM}_{5}$ (control) at 30, 45 and 60 DAS respectively (Table 2). Murugan et al., (2011), Selvakumar et al., (2012), Hussain et al., (2014) and Bahadur and Tiwari (2014) also reported similar results.

Effect of different organic nutrient management treatments on Yield and Yield attributes

An organic nutrient management practices showed significant $(p=0.05)$ effect on yield parameters and yield in green gram crop study (Table 3). The significantly highest number of pods per plant(25.93)were recorded in the plots applied $25 \%$ nitrogen through FYM, $25 \%$ nitrogen through vermicompost, Rhizobium inoculation and PSB spray @ 5ml/1 $\left(\mathrm{NM}_{4}\right)$ followed by (24.67) in application of $50 \%$ nitrogen through FYM, 50\% nitrogen through vermicompost and PSB spray @ 3ml/1 (NM3) and (23.53) in $\mathrm{NM}_{2}$ (100\% nitrogen through vermicompost) whereas these were significantly lowest (22.27)under control $\left(\mathrm{NM}_{5}\right)$ treatment. Pod per plant was recorded $16.23 \%$ higher under $\mathrm{NM}_{4}$ compared control $\left(\mathrm{NM}_{5}\right)$. Number of seeds $\left(\operatorname{pod}^{-1}\right)$ was significantly affected by different organic nutrient management treatments and followed the same trend as in number of pods (plant ${ }^{-1}$ ).

The $25 \%$ nitrogen through FYM, 25\% nitrogen through vermicompost, Rhizobium inoculation and PSB spray @ 5ml/1 $\left(\mathrm{NM}_{4}\right)$ registered significantly higher number of seeds per pod (11.47). The significantly $11.68 \%$ lower was recorded in control compared $\mathrm{NM}_{4}$. The poor growth of plants under control plots was observed. This was might be due more intra species competition for utilization of available native nutrients from the soil, which leads to lesser number of pods (plant $\left.{ }^{-1}\right)$, number of seeds $\left(\operatorname{pod}^{-1}\right)$. 
Table.1 Initial status (kharif, 2016) of soil properties at the experimental site

\begin{tabular}{|c|c|c|c|}
\hline Soil properties & $\begin{array}{c}\text { Value } \\
(0-15 \mathrm{~cm})\end{array}$ & Soil properties & $\begin{array}{l}\text { Value }(0-15 \\
\mathrm{cm})\end{array}$ \\
\hline \multicolumn{2}{|c|}{ A. Mechanical Composition } & C. Chemical properties & \\
\hline Sand $(\%)$ & 46.0 & Organic carbon (\%) & 0.71 \\
\hline Silt $(\%)$ & 24.0 & Available N (kg ha $\left.{ }^{-1}\right)$ & 287.83 \\
\hline Clay $(\%)$ & 30.0 & Available $\mathrm{P}_{2} \mathrm{O}_{5}\left(\mathrm{~kg} \mathrm{ha}^{-1}\right)$ & 12.69 \\
\hline Texture & $\begin{array}{l}\text { Sandy clay } \\
\text { loam }\end{array}$ & Available $\mathrm{K}_{2} \mathrm{O}\left(\mathrm{kg} \mathrm{ha}^{-1}\right)$ & 278.3 \\
\hline \multicolumn{4}{|c|}{ B. Physical properties } \\
\hline $\begin{array}{c}\text { Bulk density } \\
\left(\mathrm{Mg} \mathrm{m}^{-3}\right) \\
\end{array}$ & 1.45 & \multirow[t]{2}{*}{$\begin{array}{c}\mathrm{EC}\left(\mathrm{dS} \mathrm{m^{-1 } )}\right. \\
\left(1: 2 \text { soil water suspension at } 25^{0} \mathrm{C}\right)\end{array}$} & \multirow[t]{2}{*}{0.28} \\
\hline $\begin{array}{l}\text { Particle density } \\
\qquad\left(\mathrm{Mg} \mathrm{m}^{-3}\right) \\
\end{array}$ & 2.51 & & \\
\hline Porosity (\%) & 42.23 & $\begin{array}{c}\text { Soil } \mathrm{pH} \\
\left(1: 2 \text { soil water suspension at } 25^{\circ} \mathrm{C}\right)\end{array}$ & 7.3 \\
\hline
\end{tabular}

Table.2 Effect of different organic nutrient management treatments on plant height, primary branches, total dry matter of green gram

\begin{tabular}{|c|c|c|c|c|c|}
\hline \multirow[t]{2}{*}{ Treatments } & $\begin{array}{l}\text { Plant } \\
\text { height } \\
\text { (cm) }\end{array}$ & $\begin{array}{l}\text { Primary } \\
\text { branches } \\
\left.\text { (plant }^{-1}\right)\end{array}$ & \multicolumn{3}{|c|}{$\begin{array}{l}\text { Total dry matter } \\
\qquad\left(\text { g plant }{ }^{-1}\right)\end{array}$} \\
\hline & \multicolumn{2}{|c|}{ At harvest } & $\begin{array}{c}30 \\
\text { DAS }\end{array}$ & $\begin{array}{c}45 \\
\text { DAS }\end{array}$ & 60 DAS \\
\hline $\mathrm{NM}_{1}(\mathbf{1 0 0} \%$ Nitrogen through FYM) & 62.08 & 5.75 & 1.76 & 4.74 & 9.31 \\
\hline $\begin{array}{l}\mathrm{NM}_{2} \text { (100 \% Nitrogen through } \\
\text { Vermicompost) }\end{array}$ & 63.04 & 6.09 & 2.09 & 4.95 & 10.66 \\
\hline $\begin{array}{l}\mathrm{NM}_{3}(50 \% \text { Nitrogen through FYM + 50\% } \\
\text { Nitrogen through VC + PSB @3 ml/l) }\end{array}$ & 64.41 & 6.38 & 2.36 & 5.19 & 10.86 \\
\hline $\begin{array}{l}\mathrm{NM}_{4}(25 \% \text { Nitrogen through FYM + } 25 \% \\
\text { Nitrogen through VC+ Rhizobium + PSB } \\
\text { @ } 5 \mathrm{ml} / \mathrm{l})\end{array}$ & 66.32 & 6.65 & 2.60 & 5.66 & 12.61 \\
\hline $\mathrm{NM}_{5}($ Control $)$ & 61.21 & 5.25 & 1.44 & 4.38 & 8.04 \\
\hline SEm \pm & 0.39 & 0.09 & 0.04 & 0.01 & 0.01 \\
\hline C.D. $(P=0.05)$ & 1.20 & 0.28 & 0.12 & 0.02 & 0.02 \\
\hline
\end{tabular}


Table.3 Effect of different organic nutrient management treatments on yield attributes and yield in green gram

\begin{tabular}{|c|c|c|c|}
\hline Treatments & $\begin{array}{l}\text { Pods per } \\
\text { plant }\end{array}$ & $\begin{array}{l}\text { Seeds per } \\
\text { pod }\end{array}$ & $\begin{array}{l}\text { Seed yield } \\
\text { (kg/ha) }\end{array}$ \\
\hline $\mathrm{NM}_{1}(\mathbf{1 0 0} \%$ Nitrogen through FYM) & 23.13 & 10.53 & 634.60 \\
\hline $\mathrm{NM}_{2}(100 \%$ Nitrogen through Vermicompost) & 23.53 & 10.73 & 664.87 \\
\hline $\begin{array}{l}\mathrm{NM}_{3}(\mathbf{5 0} \% \text { Nitrogen through FYM + 50\% } \\
\text { Nitrogen through VC + PSB @3 ml/l) }\end{array}$ & 24.67 & 11.00 & 724.25 \\
\hline $\begin{array}{l}\mathrm{NM}_{4}(25 \% \text { Nitrogen through FYM + 25\% } \\
\text { Nitrogen through VC+Rhizobium +PSB @ 5ml/l) }\end{array}$ & 25.93 & 11.47 & 785.54 \\
\hline $\mathrm{NM}_{5}$ (Control) & 22.27 & 10.13 & 449.83 \\
\hline SEm \pm & 0.26 & 0.13 & 2.10 \\
\hline C.D. $(P=0.05)$ & 0.81 & 0.40 & 6.53 \\
\hline
\end{tabular}

Table.4 Effect of different organic nutrient management treatments on economics of green gram

\begin{tabular}{|c|}
\hline Treatments \\
\hline $\mathrm{NM}_{1}(\mathbf{1 0 0} \%$ Nitrogen through FYM) \\
\hline $\mathrm{NM}_{2}(\mathbf{1 0 0 \%}$ Nitrogen through Vermicompost) \\
\hline $\begin{array}{l}\mathrm{NM}_{3}(50 \% \text { Nitrogen through FYM + } 50 \% \\
\text { Nitrogen through VC + PSB @ 3ml/l) }\end{array}$ \\
\hline $\begin{array}{l}\mathrm{NM}_{4}(25 \% \text { Nitrogen through FYM }+25 \% \\
\text { Nitrogen through + Rhizobium +PSB @ } 5 \mathrm{ml} / \mathrm{l})\end{array}$ \\
\hline $\mathrm{NM}_{5}$ (Control) \\
\hline Mean \\
\hline
\end{tabular}

\begin{tabular}{|c|c|c|}
\hline $\begin{array}{c}\text { Gross monetary } \\
\text { returns (Rs/ha) }\end{array}$ & $\begin{array}{c}\text { Net monetary } \\
\text { returns (Rs/ha) }\end{array}$ & $\begin{array}{c}\text { B: C } \\
\text { ratio }\end{array}$ \\
\hline 49381 & 24501 & 1.98 \\
\hline 51597 & 26037 & 2.02 \\
\hline 55993 & 29303 & 2.10 \\
\hline 60446 & 36506 & 2.52 \\
\hline 35443 & 16863 & 1.91 \\
\hline $\mathbf{5 0 5 7 2}$ & $\mathbf{2 6 6 4 2}$ & $\mathbf{2 . 1 1}$ \\
\hline
\end{tabular}

Fig.1 Mean weekly meteorological data recorded during crop growing season, 2016

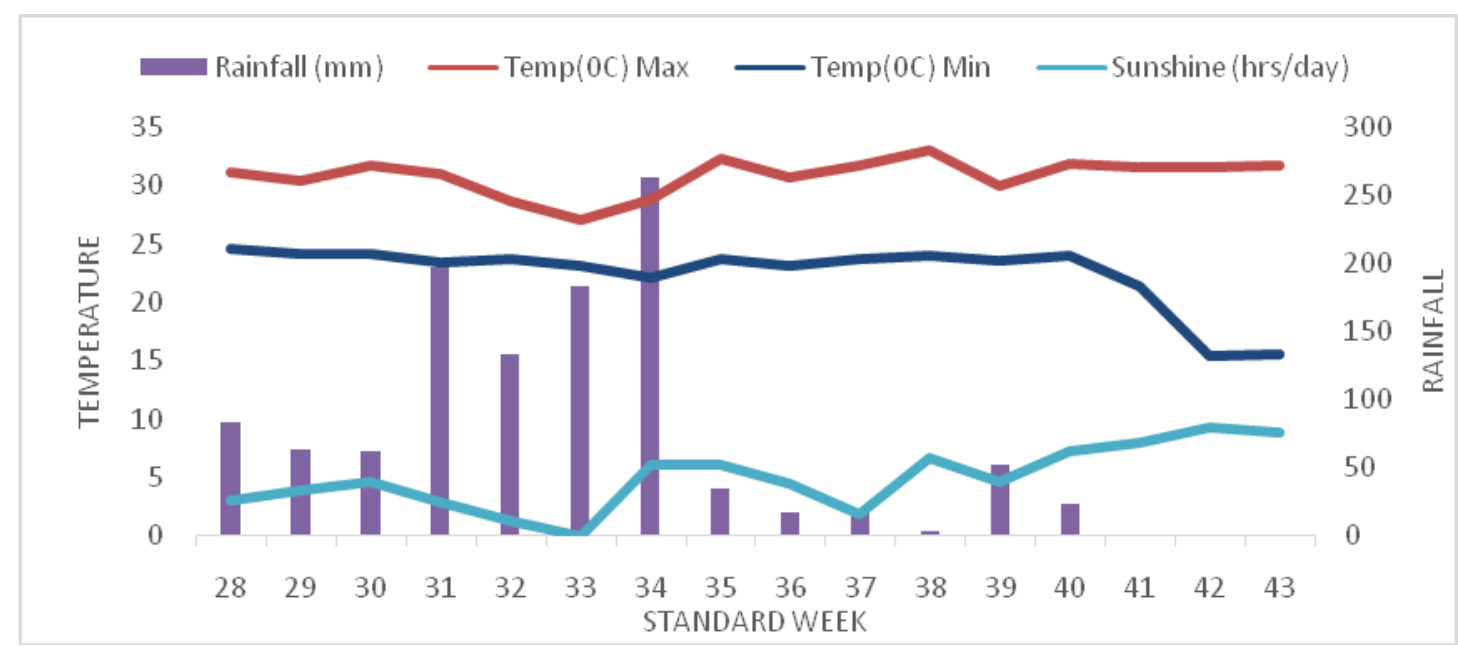


Whereas just reverse case was observed in the treatment receiving maximum nutrients $\left(\mathrm{NM}_{4}\right)$. These findings are in close conformity with the results of Murugan et al., (2011) and Bahadur and Tiwari (2014).

Seed yield recorded significantly higher with $25 \%$ nitrogen through FYM, 25\% nitrogen through vermicompost, Rhizobium inoculation and PSB spray @ 5ml/1 (785.54 $\mathrm{kg} \mathrm{ha}{ }^{-1}$ ) followed by $724.25 \mathrm{~kg} \mathrm{ha}^{-1}$ in plots given $50 \%$ nitrogen through FYM, 50\% nitrogen through vermicompost and PSB spray @ 3ml/l $\left(\mathrm{NM}_{3}\right)$. The significantly lowest seed yield (449.83 $\left.\mathrm{kg} \mathrm{ha}^{-1}\right)$ was recorded in control $\left(\mathrm{NM}_{5}\right)$ than other treatments (Table 3). Seed yield recorded $74.63 \%$ higher with $\mathrm{NM}_{4}$ compared control. Irrespective of treatments seed yield green gram was reduced in all the treatments uniformly due to rainfall at flowering and severe incidence of powdery mildew. These findings are in accordance with those of Kumawat et al., (2009), Murugan et al., (2011), Bahadur and Tiwari (2014) and Sardar et al., (2016).

\section{Effect of different organic nutrient management treatments on economics}

The maximum gross monetary returns (Rs $60446 / \mathrm{ha})$ recorded with25 \% nitrogen through FYM, 25\% nitrogen through vermicompost, Rhizobium inoculation and PSB spray @ 5ml/l $\left(\mathrm{NM}_{4}\right)$ (Table 4). In all the treatment combinations, minimum gross monetary returns (Rs 35443/ha) was recorded with NM5 (control). The Net monetary returns was maximum (Rs35506/ha) with the application of $25 \%$ nitrogen through FYM, $25 \%$ nitrogen through vermicompost, Rhizobium inoculation and PSB spray @ $5 \mathrm{ml} / 1\left(\mathrm{NM}_{4}\right)$ followed by (Rs 29303/ha) $50 \%$ nitrogen through FYM, 50\% nitrogen through vermicompost and PSB spray @ 3ml/1 (NM3) and (Rs26037/ha) plots receiving 100\% nitrogen through vermicompost $\left(\mathrm{NM}_{2}\right)$. The profitability was maximum (2.52) under the plots receiving $25 \%$ nitrogen through FYM, $25 \%$ nitrogen through vermicompost, Rhizobium inoculation and PSB spray @ $5 \mathrm{ml} / 1\left(\mathrm{NM}_{4}\right)$. The ratio was minimum (1.91) in case of control (NM5) where no any nutrient was applied. These results are in close agreements to the findings of Kumawat et al., (2009).

\section{Acknowledgements}

We also acknowledge the financial support and facilities provided by College of Agriculture, Jawaharlal Nehru Krishi Vishwa Vidyalaya, Jabalpur (M.P.) to carry out this research. Senior author is grateful to all those who contributed directly and indirectly during the course of his M. Sc research.

\section{References}

Bahadur, L. and Tiwari D.D. 2014. Nutrient management in mung bean (Vigna radiata L.) Through sulphur and biofertilizers. Legume Research.37 (2):180-187.

Chand, S. 2007. Effect of integrated nutrient management on yield and nutrient useefficiency in mustard (Brassica juncea L.). SAARC Journal of Agriculture. 5(2): 93-100.

Gratt, J.D. 1970. Earthworm Ecology. Cultural Soils, 10: 107-123.

Hussain, A., Ali, A., Khaliq, T., Ahmad, A., Aslam, Z. and Asif, M. 2014. Growth nodulation and yield components of mungbean (Vigna radiate) as affected by phosphorus in combination with rhizobium inoculation. African journal of agriculture research. 9(30): 23192323.

Kumawat, N., Sharma, O.P. and Kumar R. 2009. Effect of Organic Manures, PSB and Phosphorus Fertilization on Yield 
and Economics of Mungbean Vigna radiata (L.) Wilczek. Environment and Ecology. 27(1): 5-7.

Murugan, R., Chitrputhirapillai, S., Niemsdorff, P.F. and Nanjappan, K. 2011. Effect of combined application of biofertilizers with Neem cake on soil fertility, grain yield and protein content of Black gram. World journal of Agricultural Science. 7(5):583-590.

Potter, N.N. and Hotchkiss, J. S.1997. "Food science. CBS Publishers", New Delhi, India, pp403.

Ramesh, P., Panwar, N.R., Singh, A.B. and Ramana, S. 2008. Effect of organic manures on productivity, soil fertility and economics of soybean-durum wheat cropping system under organic farming in vertisols. Indian Journal of Agricultural Sciences. 78(4): 351-354.

Sardar, S., Kumar, Y., Shahi, U.P. Kumar, A., Dhyani, B.P., Yadav, A.K. and Singh, S.P. 2016. Effect of integrated use of bio-fertilizers and vermin Compost on nutrient availability, uptake and
Performance of urd bean (Vigna mungo) in sandy loam soil. Plant Archives 16(1): 18-22.

Selvakumar, G., Reetha, S. and Thamizhiniyan, P. 2012. Response of Biofertilizers on Growth, Yield Attributes and Associated Protein Profiling Changes of Blackgram (Vigna mungo L. Hepper). World Applied Sciences Journal 16(10): 1368-1374.

Singh, M. V. 1999. Sulphur management for oilseed and pulse crops. Indian Institutes of Soil Science (Bhopal) Bulletin No. 3. pp 2-5.

Sudhakar, G., Christopher, L.A., Rangasamy, A., Subbian, P. and Velayuthan, A. 2002. Effect of vermicompost application on the soil properties, nutrient availability, uptake and yield of rice - A review. Agriculture Review. 23(2): 127-1.

Tilak, K.V.B. 1991. Bacterial fertilizer. Indian Council of Agricultural Research New Delhi 51:1.

\section{How to cite this article:}

Kavita Bhadu, K.K. Agrawal and Rakesh Choudhary. 2018. Yield and Economics Performance of Green Gram as Influenced by Nutrient Management under Organic Farming. Int.J.Curr.Microbiol.App.Sci. 7(03): 3565-3572. doi: https://doi.org/10.20546/ijcmas.2018.703.410 